\title{
PERFORMANCE OF A GASKETED JOINT UNDER BOLT UP AND COMBINED PRESSURE, AXIAL AND THERMAL LOADING - FEA STUDY
}

Muhammad Abid ${ }^{1}$, David Hugh Nash ${ }^{2}$, Saif Javed ${ }^{3}$, Hafiz Abdul Wajid ${ }^{4}$

${ }^{1}$ COMSATS University Islamabad, Wah Campus, G.T. Road, Wah Cantt, Pakistan

${ }^{2}$ Department of Mechanical Engineering, University of Strathclyde, Glasgow, UK

${ }^{3}$ Business Development \& Planning Analyst, Philip Morris Pakistan, Pakistan

${ }^{4}$ Department of Electrical Engineering, Islamic University, Medina, KSA

\section{1drabid@ciitwah.edu.pk,2d.nash@strath.ac.uk, ${ }^{3}$ saif.javaid@gmail.com. habdulwajid@yahoo.com}

\begin{abstract}
In this paper the strength and sealing performance of a gasketed bolted flanged pipe joint is studied under bolt up and combined operating conditions using 3D nonlinear finite element analysis. The key combinations of internal pressure, axial and thermal loading are considered. The strength of the joint is seen to be affected by the axial and thermal loading combination whereas the joint sealing is seen to be dependent on the bolt up strategy during assembly and is slightly affected under pressure but only partially affected under axial loading in certain locations. Thermal loading was also considered and was found to have a significant effect on the sealing performance up to $100^{\circ} \mathrm{C}$, but beyond that no sealing was observed, resulting in the possibility of leakage and hence increasing the risk of overall joint failure. Finally, the joint load capacities are determined under various combined loadings showing its safe and unsafe operational limits.
\end{abstract}

Keywords: Gasketed, combined, loading, bolt up, axial, thermal, sealing, strength, performance, finite element analysis

\section{Notations}

$\begin{array}{ll}A L & \text { Axial loading }(\mathrm{kN}) \\ A G S S & \text { Average gasket stress }(\mathrm{MPa}) \\ D P & \text { Design pressure }(\mathrm{MPa}) \\ I P & \text { Internal pressure }(\mathrm{MPa}) \\ P T & \text { Proof test pressure }(\mathrm{MPa}) \\ S 1 & \text { Principal stress }(\mathrm{MPa}) \\ S I N T & \text { Stress intensity }(\mathrm{MPa}) \\ S Y & \text { Axial (longitudinal) stress }(\mathrm{MPa}) \\ U Y & \text { Axial displacement }(\mathrm{mm}) \\ T e m p & \text { Temperature }\left({ }^{\circ} \mathrm{C}\right) \\ H T & \text { Hub top location } \\ H B & \text { Hub bottom location } \\ H F & \text { Hub flange fillet }\end{array}$

\section{INTRODUCTION}

Conventional gasketed bolted flange joints are widely used for connecting pressure vessels and pipes in process and oil and gas industries. The performance of a gasketed flanged pipe joint is characterized by two key measures - joint strength and joint sealing. It is therefore important to evaluate its integrity and sealing performance in the actual operating condition when multiple loads are acting on the system. It is noted that the available designs rules for 
flange joints in international design codes are mainly concerned with their strength but do not sufficiently consider their sealing [1,2]. Abid et al. [3] has experimentally studied the performance of gasketed joints under bolt up and different operating conditions from a mechanical perspective i.e. combined internal pressure plus axial loading; combined internal pressure plus bending loading. However, application of thermal loading has not been considered to date, due to its complexity of application during experimental studies. In addition, Abid et al. and Fukuoka et al. [4-11] in their numerical studies have concluded that gasketed joints show better sealing performance if bolts in a joint are tightened as per ASME bolt tightening strategy [12] as compared to the various accepted industrial practices [13].

Researchers [14-20] have concluded that under additional axial loading in addition to the internal pressure, the performance of the joint is significantly affected. Abid et al [21-24] under combined internal pressure and variable temperature (static and transient) loading concluded that thermal loading becomes dominant for the failure of gasketed joint performance. In real world applications, bolted pipe joints are increasingly subjected to different structural and thermal loads in combination; even to the extent that they are subjected to thermal and pressure shocks for high end applications. In the available literature to date, no experimental or numerical studies have been observed under combined internal pressure, axial and thermal loading. From an experimental view, it is almost impossible to apply such boundary conditions to observe their behaviour in a large scale parametric study with different size ranges and classes. Therefore, keeping in mind the importance of combined axial and thermal loading, the bolted joint performance is studied under combined internal pressure (design and proof test), axial and thermal loading using detailed non-linear finite element methods. It is concluded that the methodology developed can provide a base for all sizes and classes under different combined operating conditions.

\section{GEOMETRIC MODEL, FINITE ELEMENT MODELING AND MESHING}

Figure 1 shows the key dimensions of the flange, bolts, and spiral wound gasket respectively taken from [21]. The size of gasket is taken according to the gasket suppliers as per flange size and class [28]. A complete 3D, 360 degree model of the flange joint has been developed and, due to the symmetry of the geometry and loading conditions, half the gasket thickness with flange and pipe of length $300 \mathrm{~mm}$ for one side of joint is modelled [Figure 2a]. The commercial finite element programme, Ansys, is employed and SOLID45 structural elements and SOLID70 thermal elements are used to model flange, bolt, gasket and pipe [25]. Threedimensional (3D) 'surface-to-surface' CONTA174 contact elements, in combination with TARGE170 target elements are used between the flange face and gasket, the bolt shank and flange hole, the top of the flange and the bottom of the bolt, to simulate contact distribution for both the structural and thermal effects. 3D interface elements, INTER195, are used as a special gasket element for meshing of the gasket, which is compatible with SOLID45 structural elements and SOLID70 thermal elements. The gasket meshing requires two faces i.e. source and target faces and therefore the source face, which is the top area of the gasket, is meshed with SHELL 63 elements. A total of 32639 elements are used in the complete flange joint model comprising of flange, pipe, bolts and gasket.

\section{MATERIAL PROPERTIES AND BOUNDARY CONDITIONS}

The material properties for the flange, bolt and pipe are taken from [26] and are given in Table 1. Based on the complexity in a gasketed bolted flanged pipe joint, the geometrical (contact conditions), material and loading non linearity are considered. The performance of a gasketed pipe flange joint is largely influenced by the gasket stiffness in the thickness direction, therefore, a simplified material modelling method is used due to its relative accuracy and computational cost [27]. As such, the gasket nonlinearity is considered with the 
elastic moduli during loading and unloading in each pass, directly calculated for input [Table 2]. As a benchmark problem, a flange joint size of 4 inch, 900\# Class is selected in this study with dimensions as shown below.

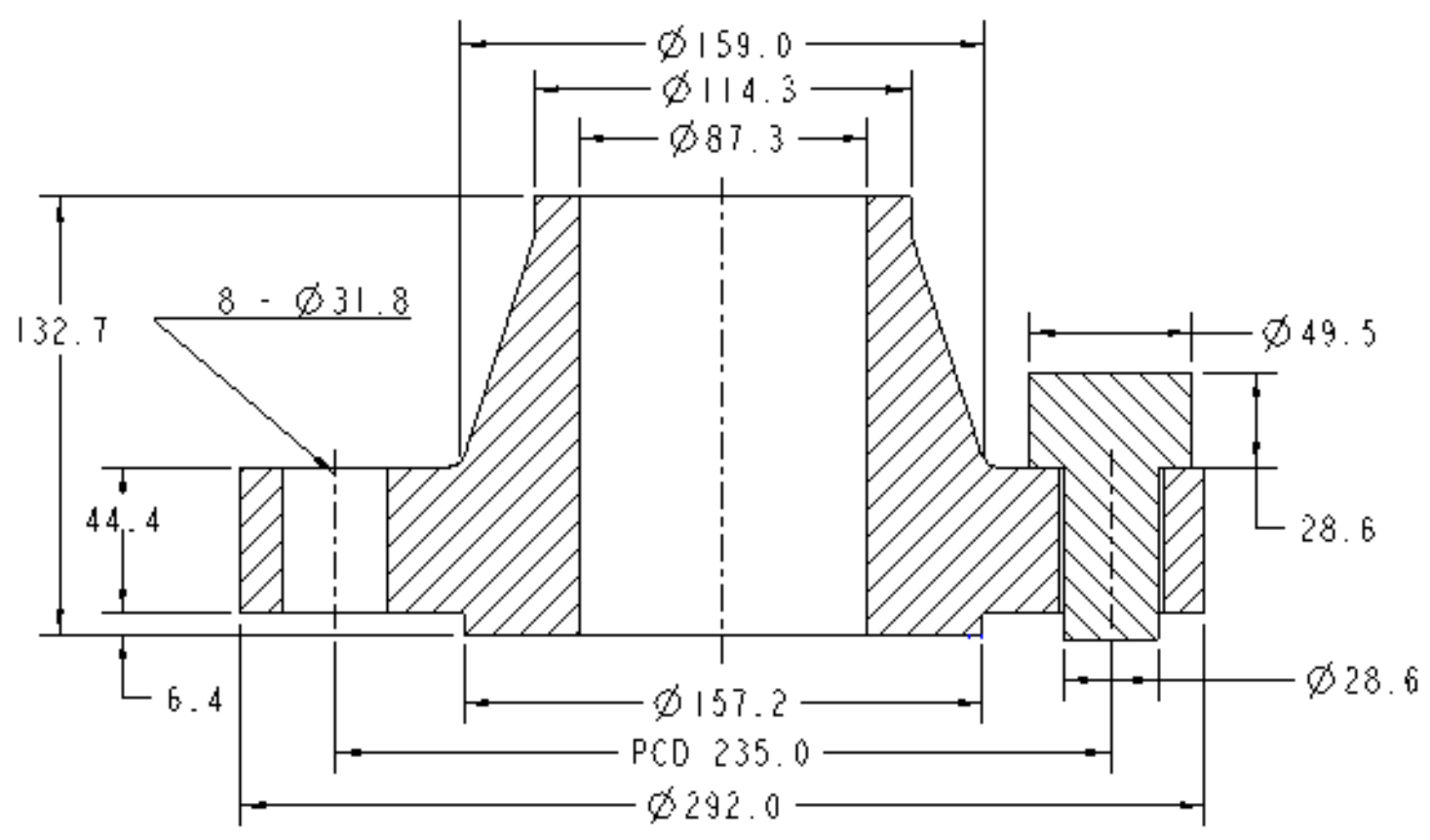

(a)

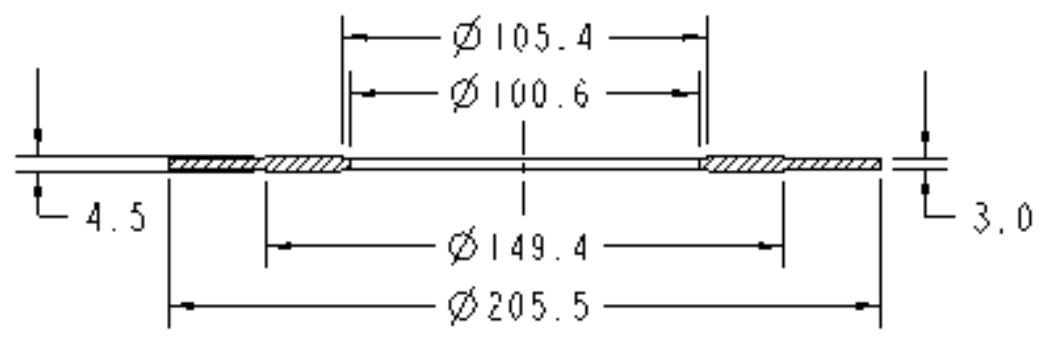

(b)

Figure 1: Joint Dimensions: (a) Pipe Flange \& Bolts (b) Spiral Wound Gasket (All Dimensions in $\mathrm{mm}$ )

Table 1: Material Properties

\begin{tabular}{|l|r|r|r|r|r|r|r|}
\hline Material & $\begin{array}{c}\text { Temp } \\
\left({ }^{\circ} \mathrm{C}\right)\end{array}$ & $\begin{array}{c}\text { Thermal } \\
\text { Conductivity } \\
k(\mathrm{~W} / \mathrm{m}-\mathrm{k})\end{array}$ & $\begin{array}{c}\text { Thermal } \\
\text { Expansion } \\
\alpha(\mathrm{m} / \mathrm{m}-\mathrm{k})\end{array}$ & $\begin{array}{c}\text { Specific } \\
\text { Heat } \\
\text { Capacity } \\
c(\mathrm{~J} / \mathrm{kg} \cdot \mathrm{k})\end{array}$ & $\begin{array}{c}\text { Poisson's } \\
\text { Ratio } \\
v\end{array}$ & $\begin{array}{c}\text { Young's } \\
\text { Modulus } \\
Y(\mathrm{MPa})\end{array}$ & $\begin{array}{c}\text { Yield } \\
\text { Strength } \\
\sigma_{Y} \\
(\mathrm{MPa})\end{array}$ \\
\hline ASTM & 20 & 47 & $12.5 \mathrm{E}-6$ & 448 & 0.3 & $1.75 \mathrm{E} 05$ & 248 \\
350 LF2 & 100 & 47 & $13.5 \mathrm{E}-6$ & 478 & 0.3 & $1.68 \mathrm{E} 05$ & 248 \\
(Flange & 200 & 46 & $14 \mathrm{E}-6$ & 508 & 0.3 & $1.62 \mathrm{E} 05$ & 241 \\
\& Pipe) & 300 & 45 & $14.4 \mathrm{E}-6$ & 548 & 0.3 & $1.56 \mathrm{E} 05$ & 238 \\
& 400 & 43 & $14.8 \mathrm{E}-6$ & 598 & 0.3 & $1.49 \mathrm{E} 05$ & 235 \\
\hline ASTM & 20 & 37 & $14.1 \mathrm{E}-6$ & 460 & 0.3 & $1.69 \mathrm{E} 05$ & 723 \\
SA193 & 100 & 37 & $15.1 \mathrm{E}-6$ & 490 & 0.3 & $1.64 \mathrm{E} 05$ & 723 \\
B7 & 200 & 36 & $15.6 \mathrm{E}-6$ & 520 & 0.3 & $1.57 \mathrm{E} 05$ & 717 \\
(Bolts $)$ & 300 & 34 & $16 \mathrm{E}-6$ & 560 & 0.3 & $1.50 \mathrm{E} 05$ & 713 \\
& 400 & 32 & $16.4 \mathrm{E}-6$ & 610 & 0.3 & $1.42 \mathrm{E} 05$ & 710 \\
\hline
\end{tabular}




\begin{tabular}{|l|r|r|r|r|r|r|r|}
\hline & 20 & 20 & $3 \mathrm{E}-6$ & 461 & 0.3 & $1.64 \mathrm{E} 05$ & 206 \\
ASTM & 100 & 20 & $4 \mathrm{E}-6$ & 491 & 0.3 & 1.59405 & 206 \\
A182 & 200 & 19 & $4.5 \mathrm{E}-6$ & 520 & 0.3 & $1.52 \mathrm{E} 05$ & 200 \\
(Gasket) & 300 & 17 & $5 \mathrm{E}-6$ & 561 & 0.3 & $1.45 \mathrm{E} 05$ & 194 \\
& 400 & 15 & $5.5 \mathrm{E}-6$ & 612 & 0.3 & $1.37 \mathrm{E} 05$ & 191 \\
\hline
\end{tabular}

Table 2: Elastic modulus calculated for each pass during loading and unloading

\begin{tabular}{|c|c|c|c|c|}
\hline \multirow{2}{*}{$\begin{array}{l}\text { Applied } \\
\text { Torque } \\
(\mathrm{Nm})\end{array}$} & \multirow{2}{*}{$\begin{array}{c}\text { Bolt } \\
\text { preload } \\
(\mathrm{kN})\end{array}$} & \multirow{2}{*}{$\begin{array}{c}\text { Average } \\
\text { Gasket stress } \\
(\mathrm{MPa}) \\
\end{array}$} & \multicolumn{2}{|c|}{ Elastic modulus (MPa) } \\
\hline & & & loading & unloading \\
\hline 210 & 37 & 30 & 319 & 3186 \\
\hline 310 & 55 & 45 & 390 & 4407 \\
\hline 400 & 70 & 60 & 450 & 5537 \\
\hline 505 & 89 & 75 & 500 & 6598 \\
\hline
\end{tabular}

\section{BOUNDARY AND CONTACT CONDITIONS}

In order to 'make' a virtual joint assembly, the bolts are constrained in radial and tangential direction and are free to elongate in the axial direction. During bolt tightening, a displacement constraint (UY) is applied at the bottom of the bolts to achieve the target pre-stress. Contact is therefore initiated between the flange face and the bottom of the bolt. Additionally, contact is established between the flange raised face bottom and the gasket top surface by applying a sufficiently small displacement at the bottom of bolts $(U Y=-0.01 \mathrm{~mm})$ in such a way that it does not produce stress in the joint components. The required target stress in the bolts is achieved by applying a second value of displacement in sequence at the bottom of the bolts. After applying pre-stress in all the bolts according to the current ASME guidelines i.e. as per sequence $1(1,3,5,7,2,4,6,8)$ in the first three passes and in last pass as per sequence 2 - chase pass $(1,2,3,4,5,6,7,8$,$) . For the operating conditions, an internal pressure equal to the design$ pressure $(15.3 \mathrm{MPa})$ and proof test pressure $(23 \mathrm{MPa})$ was applied. The end-cap loading (21.48MPa due to internal pressure) is applied to the end of the pipe as nodal forces across the walls of the pipe and at a suitable distance away from the joint. Axial load ranging from $100 \sim 400 \mathrm{kN}$ and thermal loading ranging from $100 \sim 400^{\circ} \mathrm{C}$ was applied in addition to the design and proof test pressure and the analysis was performed to investigate the overall joint behavior. All applied loading magnitudes are given in Table 3 and the applied boundary conditions are shown in Figure $2 b$.
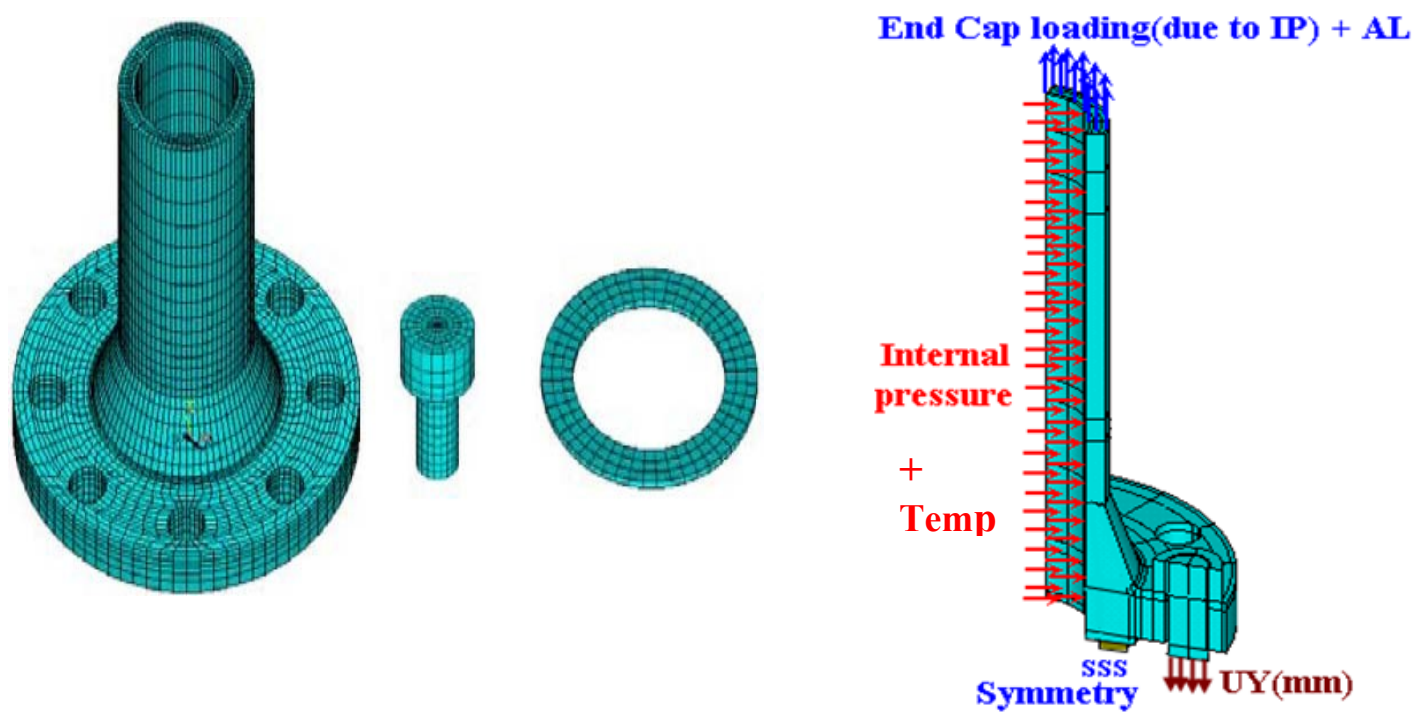
(a)

(b)

Figure 2: (a) Modeling and meshing of flange, bolt and gasket; (b) Boundary conditions 
Table 3: Loading Condition

\begin{tabular}{|l|l|}
\hline \multicolumn{1}{|c|}{ Type of Loading } & \multicolumn{1}{c|}{ Load } \\
\hline Bolt up as per ASME strategy & Torque $=700 \mathrm{Nm}$ \\
\hline $\begin{array}{l}\text { Combined Loading: } \\
\text { Internal Pressure + Axial + Thermal }\end{array}$ & Design Pressure (DP) $=15.3 \mathrm{MPa}$ \\
& $\begin{array}{l}\text { Proof Test Pressure }(\mathrm{PT})=23 \mathrm{MPa} \\
\text { Axial Loading }(\mathrm{AL})=100-400 \mathrm{kN} \\
\text { Temperature }(\mathrm{Temp})=100-400^{\circ} \mathrm{C}\end{array}$ \\
\hline
\end{tabular}

\section{FINITE ELEMENT MODEL VERIFICATION}

The FE models developed were verified under thermal and structural loading. For thermal loading, at internal and external sections of the pipe; $100^{\circ} \mathrm{C}$ surface load with convective coefficient $\left(150 \mathrm{~W} / \mathrm{m}^{2} \mathrm{~K}\right)$ and $20^{\circ} \mathrm{C}$ surface load with convective coefficient $\left(20 \mathrm{~W} / \mathrm{m}^{2} \mathrm{~K}\right)$ respectively were applied. For structural load completion, an internal pressure (DP= 15.3 $\mathrm{MPa})$ at inner pipe section and end cap loading (21.48 $\mathrm{MPa})$ at pipe end was applied. Based on wall thickness/diameter ratio $>1 / 20$, Lame's theorem was used for analytical solution. Numerical results for temperature distribution and structural stresses are measured along inside and outside wall of the pipe and are observed to be in good agreement with the analytical results [Table 4].

Table 4: Comparison between numerical and analytical results

\begin{tabular}{|c|c|c|c|c|c|c|c|}
\hline \multicolumn{3}{|c|}{ Thermal Verification } & \multicolumn{4}{c|}{ Structural Verification } \\
\hline \multicolumn{2}{|c|}{$\begin{array}{c}\text { Inside surface } \\
\text { temperature }\left({ }^{\circ} \mathrm{C}\right)\end{array}$} & \multicolumn{2}{|c|}{$\begin{array}{c}\text { Outside surface } \\
\text { temperature }\left({ }^{\circ} \mathrm{C}\right)\end{array}$} & $\begin{array}{c}\text { Inside pipe wall } \\
(\mathrm{MPa})\end{array}$ & \multicolumn{2}{c|}{$\begin{array}{c}\text { Outside pipe wall } \\
(\mathrm{MPa})\end{array}$} \\
\hline (Analytical) & $($ FEA) & $($ Analytical) & $($ FEA) & (Analytical) & $($ FEA) & (Analytical) & $($ FEA) \\
\hline 88.12 & 87.98 & 87.54 & 87.54 & 57.12 & 56.54 & 87.54 & 87.54 \\
\hline
\end{tabular}

\section{RESULTS AND DISCUSSION}

The performance of the gasketed flanged pipe joint under combined loading is discussed and summarized under various different combined loadings and sequences in the following sections.

\subsection{Design pressure plus combined loading}

In order to study the effect of loading sequence, firstly an internal pressure was applied up to design pressure $(15.3 \mathrm{MPa})$ and then an axial load was increased to $400 \mathrm{kN}$. Finally keeping axial load constant at $400 \mathrm{kN}$, the temperature was gradually increased from $100-400{ }^{\circ} \mathrm{C}$ and joint behavior was analyzed.

\subsubsection{Axial bolt stress variation}

Figure 3a shows different bolt bending behavior in each bolt during preloading when using tightening sequence 1 and 2. During the joint assembly, the axial stresses are seen to increase in bolts 1,5,3,7; whereas in bolts $2,4,6$, and 8 these show relaxation in pass 4 . Under the application of the internal (design) pressure, the axial stresses all increased in all bolts with the maximum value found in bolt $5(377 \mathrm{MPa})$. Figure $3 \mathrm{~b}$ shows the gradual increasein average bolt stress with the additional axial load of $100-400 \mathrm{kN}$. Bolt 5 shows the overall maximum stress increase of $280 \mathrm{MPa}$ at the design pressure to $302 \mathrm{MPa}$ when subjected to the axial load of $400 \mathrm{KN}$. Under the additional thermal loading $\left(100-400^{\circ} \mathrm{C}\right)$, the average bolt stresses are observed to relax with the maximum relaxation at $400^{\circ} \mathrm{C}$ in almost all the bolts 
[Figure 3c]. Overall, maximum stress in all the bolts is noted to be lower than the allowable stress of $700 \mathrm{MPa}$.

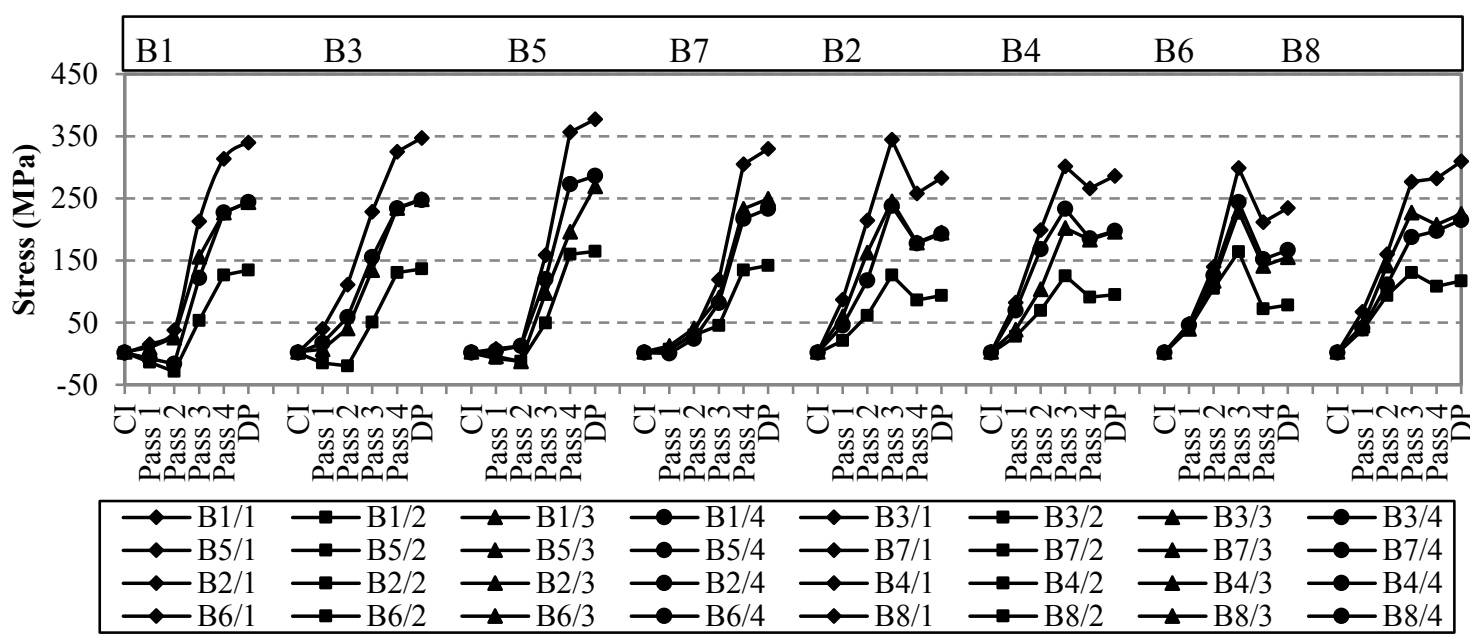

(a)

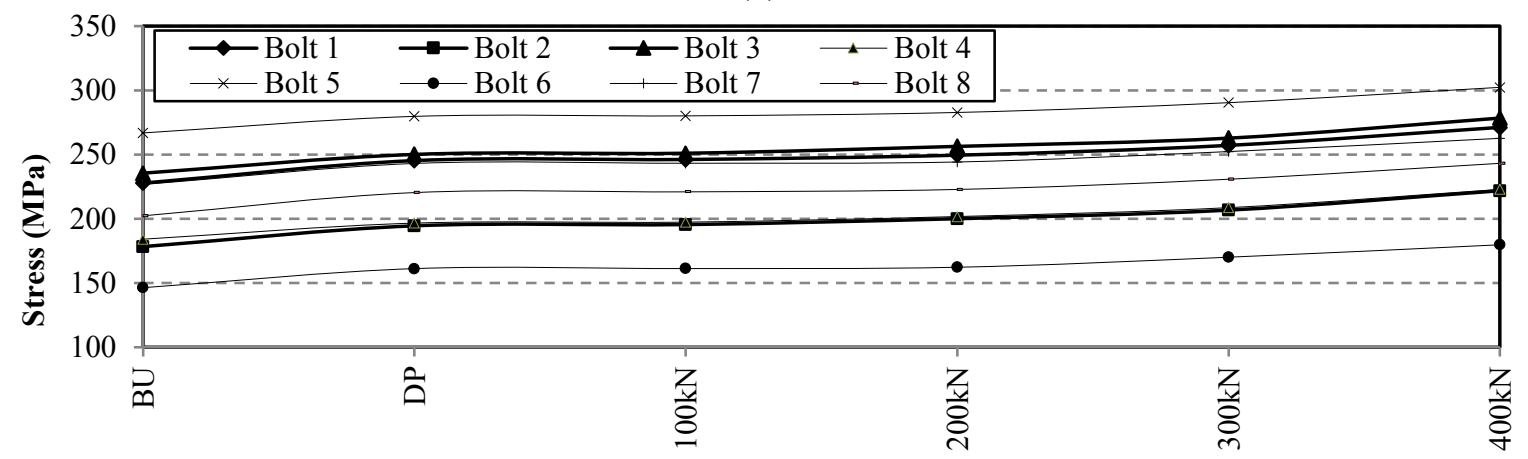

(b)

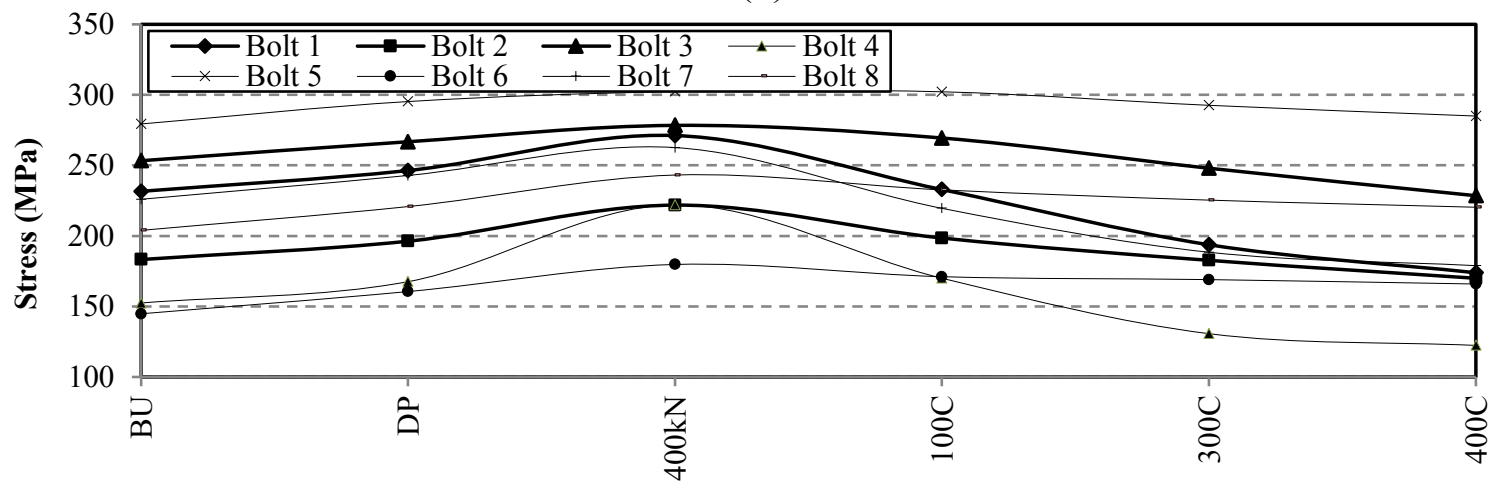

(c)

Figure 3: (a) Individual bolt bending behaviour under Bolt Up and Design Pressure; (b) Average bolt stress variations under; Bolt up + Design pressure + Axial loading (c) Average bolt stress variations under; Bolt up + Design pressure + Axial loading + Temperature

\subsubsection{Stress variation at hub flange fillet}

The principal stress, axial stress and stress intensity are found to exceed the the yield stress of flange material (248MPa) even under initial bolt up; which is then further increased under the application of the internal pressure. The maximum principal stress, stress intensity and axial stress at the design pressure all increase from $355 \mathrm{MPa}$ to $368 \mathrm{MPa} ; 285 \mathrm{MPa}$ to $298 \mathrm{MPa}$ and $236 \mathrm{MPa}$ to $240 \mathrm{MPa}$ respectively under the application of the additional axial load of $400 \mathrm{kN}$ [Figure $4(\mathrm{a})$ ]. Under the superposed thermal loading $\left(100-400^{\circ} \mathrm{C}\right)$, all measured 
stresses were observed to increase to the maximum at temperature of $100^{\circ} \mathrm{C}$; whereas under $200-400^{\circ} \mathrm{C}$, the stresses gradually decreased and the maximum stresse relaxation was observed at $400^{\circ} \mathrm{C}$ [Figure $4($ b) $]$.

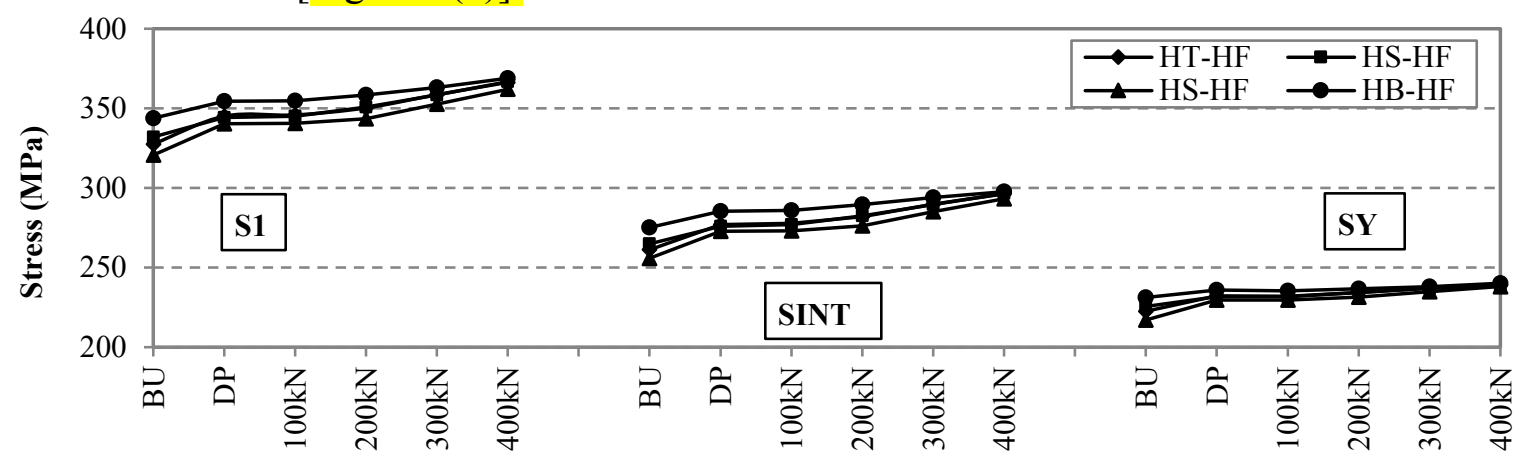

(a)

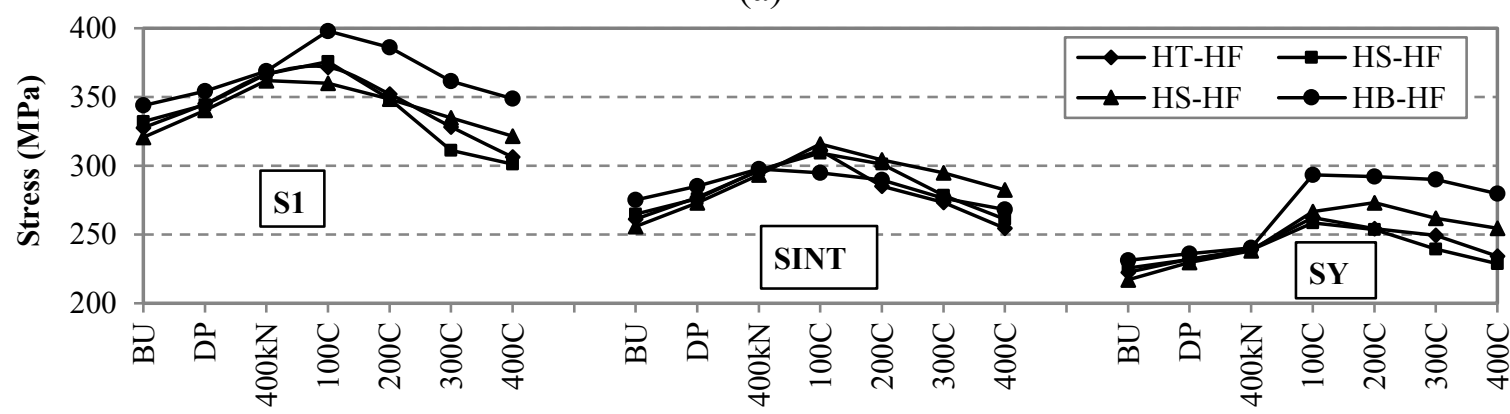

(b)

Figure 4: Flange stress variation (S1, SINT, SY) under; (a) Bolt UP + Design Pressure + Axial Loading (b) Bolt Up + Design Pressure + Axial Loading + Temperature

\subsubsection{Gasket stress variation}

The outer and inner nodes on the gasket sealing ring corresponding to the relevant bolt locations were selected in order to study the contact stress variation and hence the effect of bolt scatter on the joint sealing performance during each bolt tightening sequence on the joint. The nomenclature of the representative nodes on the gasket close to each bolt is shown in Figure 5.

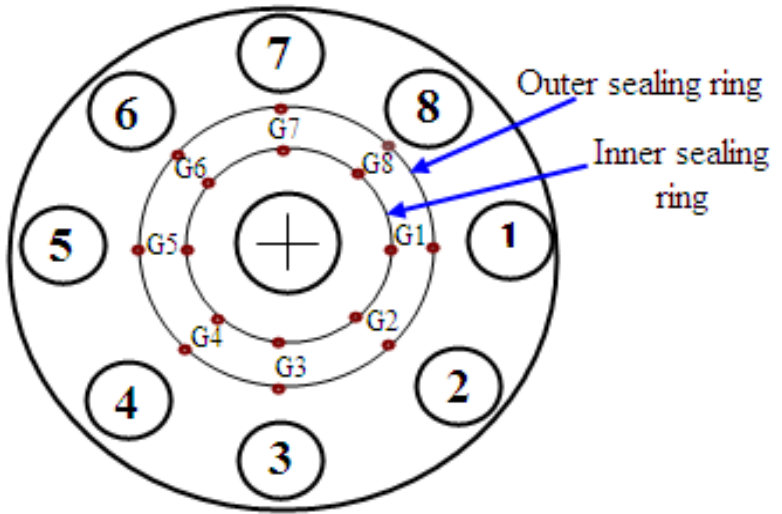

Figure 5: Nomenclatures of selected nodes on Gasket

As per gasket manufacturer specification, $68 \mathrm{MPa}$ (compressive) is the recommended seating stress of the gasket which ensures that the leakage does not take place [28]. During bolt up, the gasket stresses were found to be higher than the required seating stress $(-129 \mathrm{MPa}$ to $139 \mathrm{MPa})$; which are slightly reduced but are more than the minimum required seating stress 
of $-68 \mathrm{MPa}(-127 \mathrm{MPa}$ on outer ring and $-90 \mathrm{MPa}$ on inner ring). The conclusion therefore is that there should not be any leakage at any location. With the additional axial load of 100$400 \mathrm{kN}$, the gasket seating stress decreases to a minimum of $-114 \mathrm{MPa}$ at G6 at outer ring with the axial load applied at $400 \mathrm{kN}$. This shows sealing occurs along the outer seal ring and is due, in part, to the flange rotation. At the inner ring location, the gasket seating stress reduces to $-57 \mathrm{MPa}$ at $\mathrm{G} 6$ and $-61 \mathrm{MPa}$ at $\mathrm{G} 7$ at the applied axial load of $400 \mathrm{kN}$, resulting in the possible leakage Figure $6(\mathrm{a}, \mathrm{b})$. It is concluded that, provided there has been no relaxation during joint assembly at these locations, there should be no sealing failure as a value of $86 \mathrm{MPa}$ seating stress is achieved at all the other locations with the next 'at risk' locations being $\mathrm{G} 6$ and $\mathrm{G} 7$.

Under the additional thermal loading of $100-400^{\circ} \mathrm{C}$, the temperature effect are found to be dominant resulting in gasket seating stress relaxation lower than is at $400^{\circ} \mathrm{C}$ along $\mathrm{G} 1$ to $\mathrm{G} 4$ and G6 and at $300^{\circ} \mathrm{C}$ along G2 at outer ring. Along the inner ring, at a temperature of 200$400^{\circ} \mathrm{C}$, the minimum gasket seating stress was found to be $-50 \mathrm{MPa}$, concluding that sealing failure and possible leakage is imminent [Figure 6(c,d)].

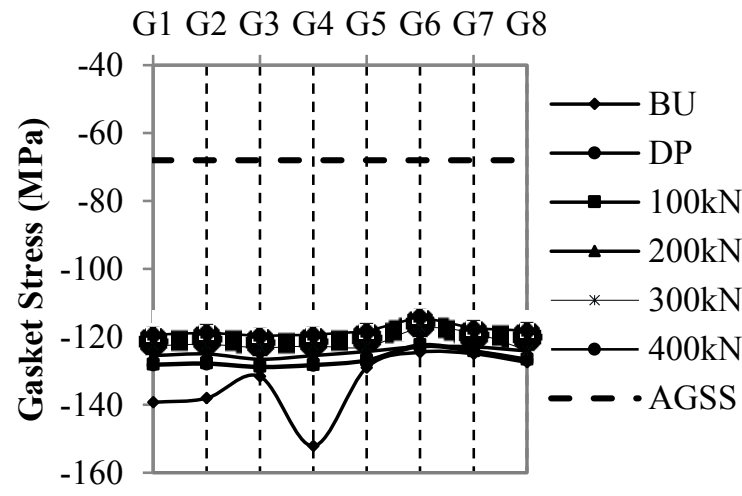

(a)

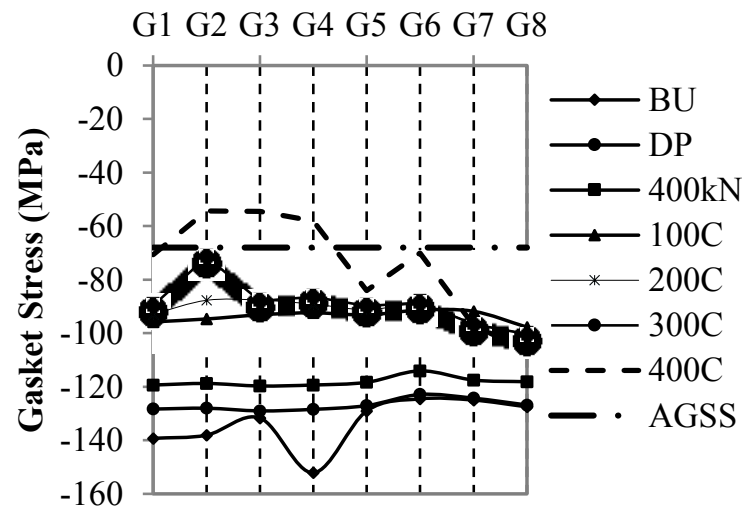

(c)

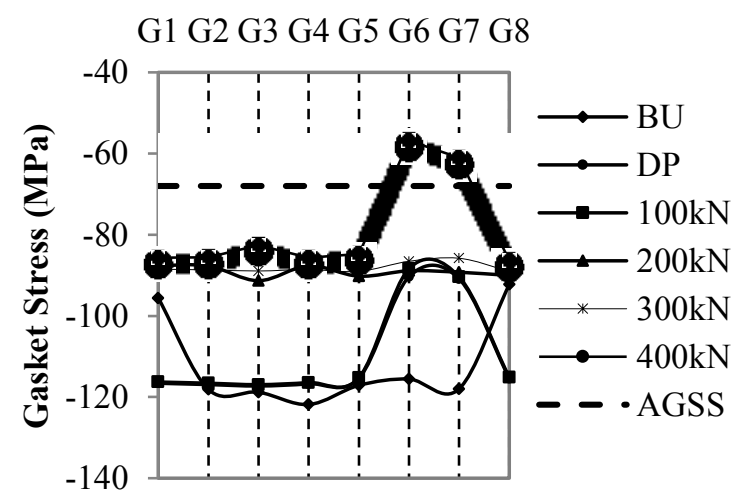

(b)

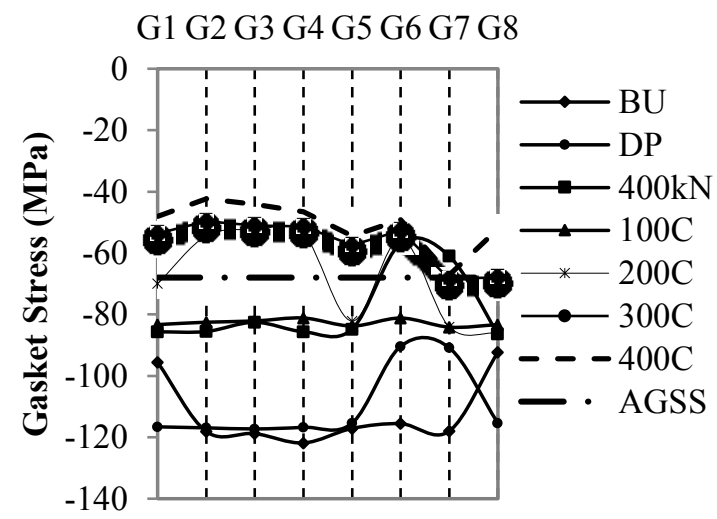

(d)

Figure 6: Gasket stress variation at Outer Sealing Ring (left column), Inner Sealing Ring (right column) under: $(\mathrm{a}, \mathrm{b})$ Bolt UP + Design Pressure + Axial Loading $(\mathrm{c}, \mathrm{d})$ Bolt Up + Design Pressure + Axial Loading + Temperature

\subsection{Proof test pressure plus Combined loading}

In order to study the effect of loading sequence, the internal pressure was first applied at the proof test pressure of $294 \mathrm{MPa}$ and the temperature was increased to $400^{\circ} \mathrm{C}$. f] Finally, the temperature was fixed at $400^{\circ} \mathrm{C}$, and the axial load was gradually increased from $100-400 \mathrm{kN}$ and the joint behaviour was assessed. 


\subsubsection{Axial bolts stress variation}

The maximum axial stress was observed in Bolt 5 at the proof test pressure (294MPa) and at the temperature of $400^{\circ} \mathrm{C}(315 \mathrm{MPa})$ respectively, which further increased to $339 \mathrm{MPa}$ with the additional axial load of $400 \mathrm{kN}$. Similarly, the minimum axial stress was observed in Bolt 4 at $167 \mathrm{MPa}$ and $125 \mathrm{MPa}$ at the proof test pressure $(167 \mathrm{MPa})$ and at temperature of $400^{\circ} \mathrm{C}$ $(152 \mathrm{MPa})$, which further increased to $152 \mathrm{MPa}$ with the additional axial load of $400 \mathrm{kN}$. Overall, the relaxation in all bolts stress was observed at $400^{\circ} \mathrm{C}$ shows dominant effect of temperature, whereas the stress increased gradually under additional axial loading.

\subsubsection{Stress at hub flange fillet}

Figure 7 shows yielding at hub flange fillet under bolt up and at the proof test pressure. Under additional axial load of $400 \mathrm{kN}$, the maximum principal stress at $200^{\circ} \mathrm{C}(388 \mathrm{MPa})$ decreased to $369 \mathrm{MPa}$; the maximum stress intensity at $200^{\circ} \mathrm{C}(264 \mathrm{MPa})$ increased to $287 \mathrm{MPa}$; and the maximum axial stress at $200^{\circ} \mathrm{C}(288 \mathrm{MPa})$ increased to $295 \mathrm{MPa}$. Under the additional axial load of $400 \mathrm{kN}$, the maximum principal stress at $400^{\circ} \mathrm{C}(383 \mathrm{MPa})$ decreased to $343 \mathrm{MPa}$; the maximum stress intensity at $400^{\circ} \mathrm{C}(291 \mathrm{MPa})$ remained constant; and the maximum axial stress at $400^{\circ} \mathrm{C}(280 \mathrm{MPa})$ increased to $296 \mathrm{MPa}$.

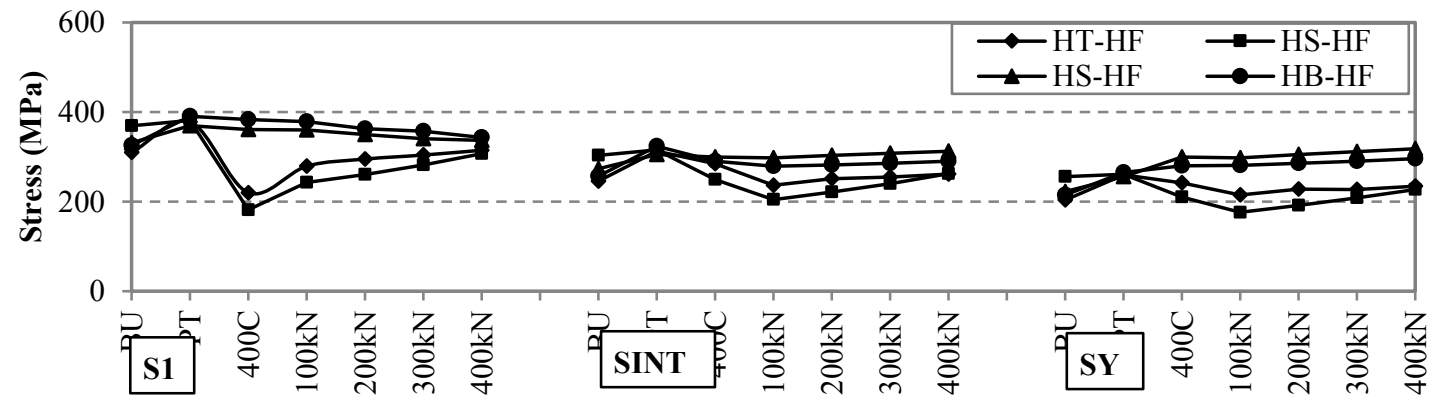

Figure 7: Flange stress variation (S1, SINT, SY) at Bolt Up + Proof test Pressure + Temperature $\left(400^{\circ} \mathrm{C}\right)+$ Axial Loading

\subsubsection{Gasket stress variation}

Under the bolt up and proof test pressure and additional axial load of $300 \mathrm{kN}$ and $400 \mathrm{kN}$, the minimum compressive gasket stress on outer seal ring of $-112 \mathrm{MPa}$ at $200^{\circ} \mathrm{C}$ was observed to decrease to $-94 \mathrm{MPa}$; whereas along the inner seal ring, the minimum gasket stress of $-89 \mathrm{MPa}$ was found to decrease to $-54 \mathrm{MPa}$ at bolt location G2, G3, G4 and G6. Under the bolt up and proof test pressure, and at the additional axial load of $400 \mathrm{kN}$, the minimum compressive gasket stress on outer seal ring of $-92 \mathrm{MPa}$ in the gasket at $400^{\circ} \mathrm{C}$ decreased to $-55 \mathrm{MPa}$ at $\mathrm{G} 2$, G3, G4; whereas along the inner seal ring, the minimum stress of $-56 \mathrm{MPa}$ decreased to $49 \mathrm{MPa}$ along all bolt locations at inner side ring [Figure 8]. This concludes this is a possible leakage path under both the axial and thermal loading conditions with higher temperature more dominant in sealing failure risk. 
G1 G2 G3 G4 G5 G6 G7 G8

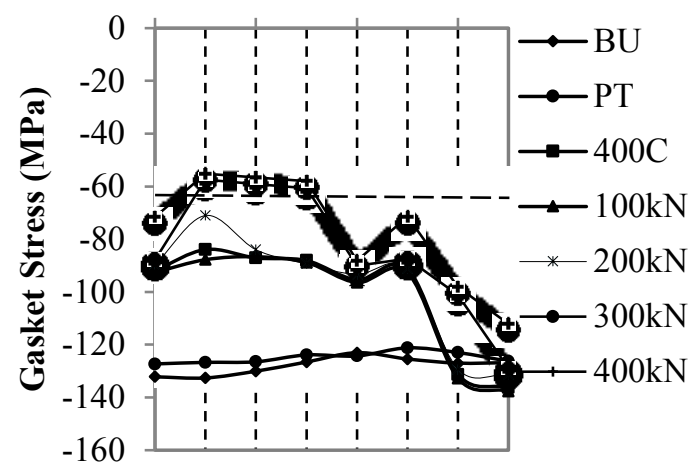

(a)
G1 G2 G3 G4 G5 G6 G7 G8

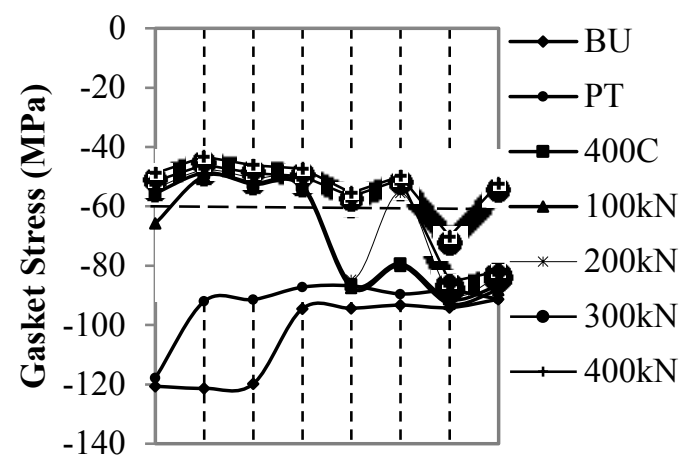

(b)

Figure 8: Gasket stress variation at; (a) Outer Sealing Ring; (b) Inner Sealing Ring under Bolt $\mathrm{Up}+$ Proof test pressure + Temperature $\left(400^{\circ} \mathrm{C}\right)+$ Axial Loading

Overall joint strength and sealing performance is summarized in Table 5 under different applied loading conditions.

Table 5: Performance (joint strength and sealing failure) under different loading

\begin{tabular}{|l|l|l|l|}
\hline \multirow{2}{*}{ Loading } & \multicolumn{2}{|c|}{ Joint Strength failure } & \multicolumn{1}{c|}{ Sealing failure } \\
\cline { 2 - 5 } & Bolts & Hub Flange Fillet & \multicolumn{1}{c|}{ Gasket } \\
\hline BU & Safe & $\begin{array}{l}\text { Unsafe at certain } \\
\text { locations }\end{array}$ & Safe \\
\hline DP+AL & Safe & $\begin{array}{l}\text { Unsafe at certain } \\
\text { locations }\end{array}$ & Unsafe at G6, G7 at 400kN \\
\hline $\begin{array}{l}\text { DP+AL }(400 \mathrm{kN}) \\
+\mathrm{TEMP}(100- \\
\left.400^{\circ} \mathrm{C}\right)\end{array}$ & Safe & $\begin{array}{l}\text { Unsafe at certain } \\
\text { locations }\end{array}$ & $\begin{array}{l}\text { Unsafe at G2, G3, G4, G6 at } 200^{\circ} \mathrm{C} \\
\text { Unsafe at all location at } 300^{\circ} \mathrm{C} \text { and } \\
400^{\circ} \mathrm{C}\end{array}$ \\
\hline $\begin{array}{l}\mathrm{PT}+\mathrm{TEMP}\left(400^{\circ} \mathrm{C}\right) \\
+\mathrm{AL}(100-400 \mathrm{kN})\end{array}$ & Safe & $\begin{array}{l}\text { Unsafe at certain } \\
\text { locations }\end{array}$ & $\begin{array}{l}\text { Unsafe at G2, G3, G4, G6 at } 200^{\circ} \mathrm{C} \\
\text { Unsafe at all location at } 200^{\circ} \mathrm{C} \text { and } \\
\text { above }\end{array}$ \\
\hline
\end{tabular}

\section{CONCLUSIONS}

Gasketed bolted flanged pipe joint behavior (strength and sealing) has been studied under bolt up and combined internal pressure, axial and thermal loading. For the specific case study considered, the maximum stresses at the bolts, pipe, hub pipes and hub center were found to be within the allowable stress under bolt up and combined loading. However at the hub flange fillet, the stresses were seen to exceed the yield stress even at the bolt up state and also under additional different combined loading therefore showing local failure. The stresses increased gradually under the design and proof test pressure and axial loading. Any additional applied thermal loading resulted in bolt stress relaxation and the possibility of flange rotation due to yielding at hub flange fillet, therefore showing its dominant role in joint integrity.

The sealing capability of the gasket bolted flanged pipe joint was found to be highly dependent on the bolt tightening strategy employed during joint assembly; which in the present study was implemented in accordance with ASME guidelines. The recommended gasket seating stress was achieved during bolt up and this slightly relaxed under the design and proof test pressure and was reasonably affected under axial load with sealing failure at certain locations. The thermal loading was shown to be a dominant effect with sealing performance 
acceptable up to $100^{\circ} \mathrm{C}$, whereas beyond that no sealing was observed leading to possible leakage and hence a joint failure scenario.

\section{REFERENCES}

1. BS 1560: Steel Pipe Flanges for the Petroleum Industry. British Standards Institution, London, UK (1989)

2. ASME Boiler and Pressure Vessel Code, Section VIII; American Society of Mech. Eng., New York, USA (1998)

3. Abid, M.: Experimental and Analytical studies of conventional (gasketed) and unconventional (non gasketed) flanged pipe joints (with special emphasis on the engineering of 'joint strength' and 'sealing'). PhD Thesis (2000). University of Strathclyde, Glasgow, UK.

4. Fukuoka, T. and T. Takaki, Evaluations of bolt-up sequence of pipe flange using threedimensional finite element analysis. ASME-publications-PVP, 1999. 382: p. 87-94.

5. Takaki T, Fkuoka T. Finite element simulation of bolt-up process of pipe flange connections. Trans ASME, J Pressure Vessel Technology. 2001;123:282-287.

6. Abid M, Khan A, Nash DH, Hussain M, Wajid HA. Optimized bolt tightening strategies for gasketed flanged pipe joints of different sizes. International Journal of Pressure Vessels and Piping. 2016;139:22-27.

7. Abid M, Khan A, Nash D, Hussain M, Wajid H. Simulation of Optimized Bolt Tightening Strategies for Gasketed Flanged Pipe Joints. Procedia Engineering. 2015;130:204-213.

8. Khan K, Abid M, Chattha J. Gasketed bolted flange joint's relaxation behaviour under different bolt up strategy. Proceedings of the Institution of Mechanical Engineers, Part E: Journal of Process Mechanical Engineering. 2009;223(4):259-263.

9. Abid, M. and S. Hussain, Bolt preload scatter and relaxation behaviour during tightening a 4 in900\# flange joint with spiral wound gasket. Proceedings of the Institution of Mechanical Engineers, Part E: Journal of Process Mechanical Engineering, 2008. 222(2): p. 123-134.

10. Abid M, Khan A, Hussain M, Wajid HA. Optimized bolt tightening procedure for different tightening strategies - FEA study. Proceedings of the Institution of Mechanical Engineers, Part E: Journal of Process Mechanical Engineering. 2015:0954408915589687.

11. Abid M, Abdul Wajid H, Abbas A, Mehmood Y. Assembly performance of a gasketed bolted flanged pipe joint using different bolt tightening strategies. Iranian journal of science and technology transactions of mechanical engineering. 2015;39:253-260.

12. ASME PCC-1, 2000: Guidelines for pressure boundary bolted flange joint assembly.

13. ES/090 Rev:1.Design and Engineering Practices (DEPs),DEP 31.38.01.15.Gen (Piping Class Exploration and Production) 1998.

14. Abid M. Stress variation in the flange of a gasketed flanged pipe joint during bolt up and operating conditions. Scientia Iranica. 2006;13(3):303-9.

15. Abid M, Khan NB, editors. Stamina of a Gasketed Flange Joint Under Combined Internal Pressure and Axial Loading. ASME 2010 10th Biennial Conference on Engineering Systems Design and Analysis; 2010: American Society of Mechanical Engineers.

16. Abid M. Performance testing of gasketed flange joint under combined loading. Proceedings of the Institution of Mechanical Engineers, Part E: Journal of Process Mechanical Engineering. 2009;223(2):91-5.

17. Khan NB, Abid M, Jameel M, Wajid HA. Joint strength of gasketed bolted pipe flange joint under combined internal pressure plus axial load with different (industrial and ASME) bolt-up strategy. Proceedings of the Institution of Mechanical Engineers, Part E: Journal of Process Mechanical Engineering. 2015:0954408915614460.

18. Abid M. Comparative performance study of gasketed and non-gasketed flange joints under combined internal pressure, axial and bending loading-an experimental study. IIUM Engineering Journal. 2010;11(2):179-200.

19. Cao, J. and A. Bell, Elastic analysis of a circular flange joint subjected to axial force. International journal of pressure vessels and piping, 1993. 55(3): p. 435-449.

20. Abid M.; Nash D. H.; Javed S.; Rizvi S. T. H.: 3-D Nonlinear FEA of a gasketed flange joint under bolt up and combined internal pressure, temperature, axial and bending loading. 
International Conference on Pressure Vessel Technology (ICPVT-13) 21-23 May 2012, London, UK. Pp.1-13.

21. Abid M.; Ullah B.; Three Dimensional Nonlinear Finite Element Analysis of Gasketed Flange Joint under Combined Internal Pressure and Variable Temperatures. Journal of Engineering Mechanics, Vol. 133/2 pp. 222-229 (2007)

22. Abid M.; Khan K. A.; Chattha J. A.: Performance testing of a gasketed bolted flange pipe joint under combined pressure and thermal loading. Experimental Techniques, pp. 1-3 (2011).

23. Abid M.; Khan K. A; Chattha J. A.: Finite Element Analysis of a Gasketed Flange Joint under Combined Internal Pressure and Thermal Transient Loading. July 22-26, 2007, ASME PVP200726602.

24. Nelson NR, Prasad NS, Sekhar A. Effect of thermal loading on sealing behavior of single and twin-gasketed flange joints. Proceedings of the Institution of Mechanical Engineers, Part E: Journal of Process Mechanical Engineering. 2015:0954408915574295.

25. ANSYS Inc.: ANSYS elements manual, 11th edition (2009)

26. ASME Boiler and Pressure Vessel Coe, Section VIII, Part D, American Society of Mech. Eng, New York, USA (1998).

27. Nagata, S; Shoji, Y.; Toshiyuki, S.: A Simplified Modeling of Gasket Stress-Strain Curve For FEM Analysis In Bolted Flange Joint Design. Vol. 433, pp. 53-58. ASME International PVP Conference, 2002, BC Canada.

28. http://www.klinger.co.uk 